\section{Preplant Drip-applied Fumigation for Calla Lily Rhizome Nursery}

\author{
James S. Gerik ${ }^{1}$, Ian D. Greene ${ }^{2}$, Peter Beckman², and \\ Clyde L. Elmore ${ }^{3}$
}

AdDitional INDEX wORDs. methyl bromide, 1,3-dichloropropene, chloropicrin, iodomethane, metham sodium, sodium azide, furfural, floriculture, Zantedeschia

Summary. Two field trials were conducted from 2002 until 2004 to evaluate several chemicals as alternatives to methyl bromide for the production of calla lily (Zantedeschia sp.) rhizomes. Various rates and chemical combinations were tested. The chemicals were applied through a drip irrigation system. The chemicals included iodomethane, chloropicrin, 1,3-dichloropropene, metham, sodium furfural, and sodium azide. None of the treatments reduced the viability of seed of mallow (Malva parviflora) previously buried in the plots. Propagules of nutsedge (Cyperus esculentus) and seed of mustard (Brassica nigra) were controlled by iodomethane + chloropicrin, 1,3-dichloropropene + chloropicrin, chloropicrin alone, 1,3-dichloropropene alone, and furfural + metham sodium. Propagules of calla were controlled by all of the treatments except sodium azide and furfural + metham sodium. In the first trial, all treatments reduced the populations of soilborne plant pathogens, including Pythium spp., Phytophthora spp., and Fusarium oxysporum, except for sodium, which did not reduce the population of Phytophthora spp. In the second trial, all treatments controlled Pythium spp. but only a high rate of iodomethane + chloropicrin reduced the population of $F$. oxysporum. For all treatments, the incidence of disease caused by soilborne pathogens was reduced compared to the nontreated control. The number and value of harvested rhizomes were greater among all of the treatments, except for sodium azide, compared to the control. The harvested value of the crop for the best treatments increased significantly compared to the control. A successful crop of calla rhizomes can be produced by combinations of iodomethane, chloropicrin, 1,3-dichloropropene, and metham sodium.

$\mathrm{E}$ ach year in Monterey and Santa Cruz counties of California, about 300 acres of hybrid colored calla lily are planted from true seed in what is the start of a 2 -year crop. While cut flowers may be harvested during the growing seasons, the main product, the rhizomes, are harvested following the second season (Kuehny, 2000 ). The rhizomes are used to produce flowering potted plants for sale at the retail level, as well as for the production of wholesale cut flowers.

Calla lily is susceptible to several soilborne pathogens which can limit production and lower quality of the rhizome. These include root rots caused by Pythium and Phytophthora spp. as well as soft rot of the rhizomes due to Erwinia spp. (Dreistadt, 2001). To

${ }^{1}$ San Joaquin Valley Agricultural Sciences Center, USDAARS, 9611 S. Riverbend Ave., Parlier, CA 93648.

${ }^{2}$ Golden State Bulb Growers Inc., 1260 Highway 1, Moss Landing, CA 95039.

${ }^{3}$ University of California Weed Science Program, One Shields Avenue, Davis, CA 95616.

Acknowledgments. The authors thank Susan Vail, Ernie Leyva, and Patricia Martinez for technical assistance, and Justin Brown of Golden State Bulb Growers for hosting the trials. This research was supported in part by grants from the California Cut Flower Commission. control soilborne pathogens, as well as weeds, calla nursery soils are routinely fumigated with formulations of methyl bromide $(\mathrm{MB})$ and chloropicrin $(\mathrm{CP})$ before planting. These preplant treatments greatly reduce disease and weed pressure and improve the quality of the harvested rhizome. However, MB has been found to be an atmospheric ozone depleting compound and its production and importation have been banned in the U.S. since l Jan. 2005, except for quarantine and some approved critical use purposes (U.S. Environmental Protection Agency, 1993; Watson et al., 1992). Several alternative chemical treatments have been proposed for use on floriculture as well as other crops. These include iodomethane (IM), 1,3-dichloropropene (DP), metham sodium (MS), furfural (F), and sodium azide $\left(\mathrm{NaN}_{3}\right)$ (Ajwa and Trout, 2004; Fennimore et al., 2003; Gerik, 2005a, 2005b; Gilreath et al., 2004a, 2004b, 2006; Kabir et al., 2005). These alternative chemicals have been tested by shank application, as well as application through drip irrigation systems (Ajwa et al., 2002).

From 2002 until 2004, two experiments were established to evaluate alternative fumigants applied through the drip irrigation systems for calla lily rhizome production in California. This research was crucial not only to provide economical alternatives for floriculture production, but also to secure critical use exemptions to continue using $\mathrm{MB}$ in areas where drip fumigation cannot be used.

\section{Materials and methods}

Both trials were conducted on beds 50 inches wide and 72 inches center-to-center. In both trials fumigants were delivered in the irrigation water. Fumigants used in these studies included IM:CP (Midas; Arvesta, San Francisco); DP (Telone EC and InLine; Dow AgroSciences, Indianapolis); CP (Tri-Clor EC; TriCal, Hollister, Calif.); F (Multiguard; Harborchem, Cranford, N.J.); $\mathrm{NaN}_{3}$ (SEP-100; American Pacific, Las Vegas, Nev.); and MS (Vapam HL; AMVAC Chemical, Los Angeles). Fumigants and irrigation water were applied through four low flow $(0.67 \mathrm{gal} / \mathrm{min}$, emitter spacing 8.5 inches) drip tapes (Tiger Tape; Valplastic, Ontario, Calif.) equally spaced across the bed and buried about 2 inches deep. Each tape was cut at the ends of each plot and one end connected with fittings to a water delivery manifold made of $3 / 8$-inch (i.d.) polyethylene tubing; the other end of the tape was sealed. Each of the manifolds from plots of like treatments was connected together and to the fumigant injection manifold. The plots were covered with polyethylene film

\begin{tabular}{llll}
\hline $\begin{array}{l}\text { Units } \\
\text { To convert U.S. to SI, } \\
\text { multiply by }\end{array}$ & U.S. unit & SI unit & $\begin{array}{l}\text { To convert SI to U.S., } \\
\text { multiply by }\end{array}$ \\
\hline 0.4047 & acre $(\mathrm{s})$ & $\mathrm{ha}$ & 2.4711 \\
0.3048 & $\mathrm{ft}$ & $\mathrm{m}$ & 3.2808 \\
3.7854 & gal & $\mathrm{L}$ & 0.2642 \\
9.3540 & gal/acre & $\mathrm{L}_{\mathrm{ha}}{ }^{-1}$ & 0.1069 \\
2.54 & inch(es) & $\mathrm{cm}$ & 0.3937 \\
25.4 & inch(es) & $\mathrm{mm}$ & 0.0394 \\
1.1209 & lb/acre & $\mathrm{kg} \cdot \mathrm{ha}^{-1}$ & 0.8922 \\
1.6093 & mile(s) & $\mathrm{km}$ & 0.6214 \\
28.3495 & $\mathrm{oz}$ & $\mathrm{g}$ & 0.0353
\end{tabular}


(1 mil thick) before treatments were applied. The fumigants were injected and thoroughly mixed into the irrigation stream by the method previously described by Ajwa et al. (2002). The chemical manufacturers formulated the chemicals with emulsifiers except for the metham sodium and sodium azide formulations, both of which are sufficiently soluble in water. All rates listed are for active ingredients and the rates applied were based on the 50 -inch bed width.

2002 Trial. A field trial was established about 3 miles northeast of Marina, Calif. (Monterey County), on Oceano sand (sand $89 \%$, silt $7 \%$, clay $4 \%$, organic matter $0.6 \%$ ). Each plot in this trial was $20 \mathrm{ft}$ long. Chemicals were applied through the drip irrigation tape in either 1 or 2 inches of water (based on bed width) on 2 and 3 May 2002 (four treatments each day). A split-plot design with six replications was utilized; the main plots were the amount of water used, and the subplots were the chemicals applied. A standard MB:CP treatment was not included because an emulsified formulation of this treatment did not exist and the small size of the plots precluded use of standard shank application equipment. The treatments were 1 ) water (control);2) $\mathrm{NaN}_{3}$ at $100 \mathrm{lb} /$ acre; 3$) \mathrm{F}: \mathrm{MS}(67: 33)$ at $700 \mathrm{lb} /$ acre; 4) DP at $24 \mathrm{gal} / \mathrm{acre}$; $5) \mathrm{DP}: \mathrm{CP}$ at $50 \mathrm{gal} / \mathrm{acre}$; 6) IM:CP (50:50) at $300 \mathrm{lb} / \mathrm{acre} ; 7)$ IM:CP (33:67) at $400 \mathrm{lb} /$ acre; and 8) CP at $400 \mathrm{lb} / \mathrm{acre}$. Prior to treatment, sachets containing either seed of mustard or mallow, and rhizomes of nutsedge were buried in each plot at 6-inch depth. Two weeks after treatment, the sachets were removed and the viability of the seed and rhizomes was determined by placing them on moist blotters in petri dishes and observing any growth. Soil samples and weed data (counts of the major germinating weeds indigenous in the soil, referred to as the weed seed bank) were also collected at this time. The soil samples comprised five pooled soil cores $(1 \times 6$ inches $)$ taken at 5 - $\mathrm{ft}$ intervals in the middle of the bed. The soil samples were returned to the laboratory and allowed to air dry at room temperature for 2 weeks. Populations of Pythium spp., Phytophthora spp., and F. oxysporum were determined in the soil samples by dilution plating on Martin's (Martin, 1992), PARPH (Jeffers and Martin, 1986), and Komada's (Komada, 1975) media, respectively.
Even though $F$. oxysporum is not a pathogen of calla lily, its population was determined as a general indication of treatment efficacy. Population determination of Erwinia carotovora, a major pathogen of calla lily, was not attempted.

Twelve rows of calla ('Garnet Glow') were planted per bed with true seed on 3 June 2002 and emergence counts were made on 13 Aug. 2002. During the winter, the plants went dormant and all foliage died. New sprouts emerged the following spring. On 27 June 2003 disease incidence was determined by visual symptoms. Disease symptoms progressed from chlorosis to necrosis to eventually death. Roots on symptomatic plants were severely decayed. Pythium spp. were routinely isolated from these roots and these isolates caused root decay on greenhouse-grown calla lily. Although other pathogens were sometimes recovered, these were not tested for pathogenicity.

Harvest began on 20 Oct. 2003. Rhizomes were lifted and laid down on the soil surface with the aid of a potato digger. Rhizomes were placed in trays by hand and taken to the grower's facility where they were graded according to size and salability, as is customary with this crop. The grades ranged from less than $1-1 / 4$ inch diameter to 3 inches or greater diameter in quarter-inch size ranges. Rhizomes that were cut or exhibited decay were deemed nonsalable. A value was assigned to each size of rhizome and the total value for each $2 \mathrm{~m}$ of bed was calculated.

2003 Trial. A second trial was established near Amesti, Calif. (Santa Cruz County), on Elder sandy loam (sand $53 \%$, silt $25 \%$, clay $22 \%$, organic matter $2.0 \%$ ). Each plot in this trial was $100 \mathrm{ft}$ long; the materials were applied in 1.5 inches of water. The poorer-performing treatments from the first trial were eliminated and additional rates and other formulations were added. The rates of the DP:CP treatments were reduced to what is thought to be more affordable rates. All treatments were applied as before. The nine treatments in this trial included: 1) water (control); 2) DP:CP at 20 gal/acre; 3 ) DP:CP at $38 \mathrm{gal} / \mathrm{acre}$; 4) IM:CP (50:50) at $150 \mathrm{lb} /$ acre; 5 ) IM:CP (50:50) at $300 \mathrm{lb} /$ acre; 6) IM: $\mathrm{CP}(33: 67)$ at $200 \mathrm{lb} / \mathrm{acre} ; 7) \mathrm{IM}: \mathrm{CP}$ $(33: 67)$ at $400 \mathrm{lb} /$ acre; 8$) \mathrm{CP}$ at 200 $\mathrm{lb} /$ acre; and 9) $\mathrm{CP}$ at $300 \mathrm{lb} /$ acre.
Both of the CP-alone treatments were also treated with $75 \mathrm{gal} / \mathrm{acre}$ of MS 1 week after the initial treatment. The two chemicals could not be applied together because of incompatibility (Ajwa and Trout, 2004; Guo et al., 2005). Weeds were not buried in sachets in the second trial. Soil samples were collected and processed as before. The treatments were made on 22 May 2003 and 12 rows of calla ('Crystal Blush') were planted 12 June 2003. On 2 July 2003 , counts of nutsedge were made from each of the whole plots. Counts of volunteer calla from the previous crop were also made on this date from the whole plot. Emergence counts were made on 4 Sept. 2003. Disease incidence was determined the following summer on 13 July 2004 as before. On 15 Dec. 2004 the entire plot was mechanically harvested by the grower, using his customary equipment. The rhizomes were again graded for size and salability and their value determined as before.

Data anAlyses. Analysis of variance was performed using the PROC GLM of SAS (SAS Institute, Cary, N.C.) and means were separated according to Fisher's protected least significant difference test for all data.

\section{Results and discussion}

The amount of water used to apply the chemicals in the 2002 trial had little effect on the efficacy of the treatments. For two parameters (mortality of mustard seed and nutsedge buried in sachets) the 2 -inch treatment improved control, but seeded calla emergence was greater and disease incidence was less for the 2 -inch treatment (Tables 1 and 2). The amount of water used had no other significant effect on the measured parameters and there was no interaction between the water and chemical treatments; the two water treatments were combined in the analysis of the chemical treatments. The additional water may have been conducive to more seedling damping-off, and would have reduced the chemical concentrations, reducing their effectiveness, although the pathogen population data does not indicate a decrease in efficacy (data not shown). Ajwa and Trout (2004) have shown improved fumigant distribution and higher fumigant soil gas concentrations when applied with $61 \mathrm{~mm}$ of water compared to $26 \mathrm{~mm}$ of water.

Most of the applied chemical 
Table 1. Mortality of weed propagules in sachets buried 6 inches $(15.2 \mathrm{~cm})$ deep in the soil before treatment with various chemicals applied by drip irrigation, and emergence of weeds from the soil weed bank in Marina, Calif., during May 2002. Sachets were collected and weed counts were made 2 weeks following chemical application.

\begin{tabular}{|c|c|c|c|c|c|c|}
\hline Treatment $^{\mathrm{z}}$ & $\begin{array}{c}\text { Nutsedge } \\
(\% \text { mortality })^{\mathrm{y}, \mathrm{x}}\end{array}$ & $\begin{array}{c}\text { Mustard } \\
(\% \text { mortality })^{\mathrm{w}}\end{array}$ & $\begin{array}{c}\text { Calla } \\
\text { (no. of buds } \\
\text { growing from } \\
\text { five rhizomes) }\end{array}$ & $\begin{array}{c}\text { Mallow } \\
\text { emergence from } \\
\text { weed seed bank } \\
\text { (no.) }\end{array}$ & $\begin{array}{c}\text { Common groundsel } \\
\text { emergence from } \\
\text { weed seed bank } \\
(\text { no. })^{\mathrm{v}}\end{array}$ & $\begin{array}{c}\text { Clover }^{\mathrm{v}} \\
\text { emergence from } \\
\text { weed seed bank } \\
\text { (no.) }\end{array}$ \\
\hline IM:CP 50:50-300 & $100 \mathrm{a}$ & $93.9 \mathrm{a}$ & $0 \mathrm{c}$ & $0 \mathrm{~b}$ & $0 \mathrm{~b}$ & $0.1 \mathrm{~b}$ \\
\hline DP:CP-50 & $100 \mathrm{a}$ & $94.8 \mathrm{a}$ & $0 \mathrm{c}$ & $0 \mathrm{~b}$ & $0 \mathrm{~b}$ & $0.3 \mathrm{~b}$ \\
\hline DP-24 & $33.3 \mathrm{bc}$ & $100 \mathrm{a}$ & $0 \mathrm{c}$ & $0 \mathrm{~b}$ & $0.2 \mathrm{~b}$ & $0.2 \mathrm{~b}$ \\
\hline $\mathrm{NaN3}$ & $17.4 \mathrm{~cd}$ & $48.6 \mathrm{c}$ & $2.1 \mathrm{a}$ & $0 \mathrm{~b}$ & $2.2 \mathrm{~b}$ & $1.3 \mathrm{~b}$ \\
\hline Control & $8.1 \mathrm{~d}$ & $13.9 \mathrm{~d}$ & $1.5 \mathrm{ab}$ & $2 \mathrm{a}$ & $8.9 \mathrm{a}$ & $6.3 \mathrm{a}$ \\
\hline
\end{tabular}

IM:CP 33:67-400 = iodomethane + chloropicrin (33:67) at $400 \mathrm{lb} /$ acre; IM:CP 50:50-300 = iodomethane + chloropicrin $(50: 50)$ at 300 lb/acre; DP:CP-50 = 1,3-di chloropropene + chloropicrin (61:33) at $50 \mathrm{gal} / \mathrm{acre} ; \mathrm{DP}-24=1,3$-dichloropropene at $24 \mathrm{gal} / \mathrm{acre} ; \mathrm{CP}-400)$ chloropicrin at $400 \mathrm{lb} / \mathrm{acre} ; \mathrm{F}: \mathrm{MS}=$ furfural at $480 \mathrm{lb} / \mathrm{acre}+$ metham sodium at $210 \mathrm{lb} / \mathrm{acre} ; \mathrm{NaN}_{3}=$ sodium azide at $100 \mathrm{lb} / \mathrm{acre}$, and a untreated control $\left(1.0 \mathrm{lb} / \mathrm{acre}=1.1209 \mathrm{~kg} \cdot \mathrm{ha}^{-1} ; \mathrm{l} \mathrm{gal} / \mathrm{acre}=9.3540 \mathrm{~L} \cdot \mathrm{ha}{ }^{-1}\right)$.

${ }^{y}$ Means not followed by the same letter are significantly different according to Fisher's protected least significant difference test $(P \leq 0.05)$.

xThe mortality of the nutsedge was significantly greater in the 2 -inch $(51 \mathrm{~mm})$ water treatment $(68.2 \%)$ compared to the 1 -inch $(25 \mathrm{~mm})$ water treatment $(58.1 \%)$.

whe mortality of the mustard was significantly greater in the 2 -inch water treatment $(81.3 \%)$ compared to the 1 -inch water treatment $(69.8 \%)$.

${ }^{v}$ Common groundsel (Senecio vulgaris), clover (Trifolium spp.).

Table 2. Emergence, pathogen populations, disease incidence, and yield data of calla lily rhizomes after treatments with various chemicals applied by drip irrigation in Marina, Calif., during May 2002.

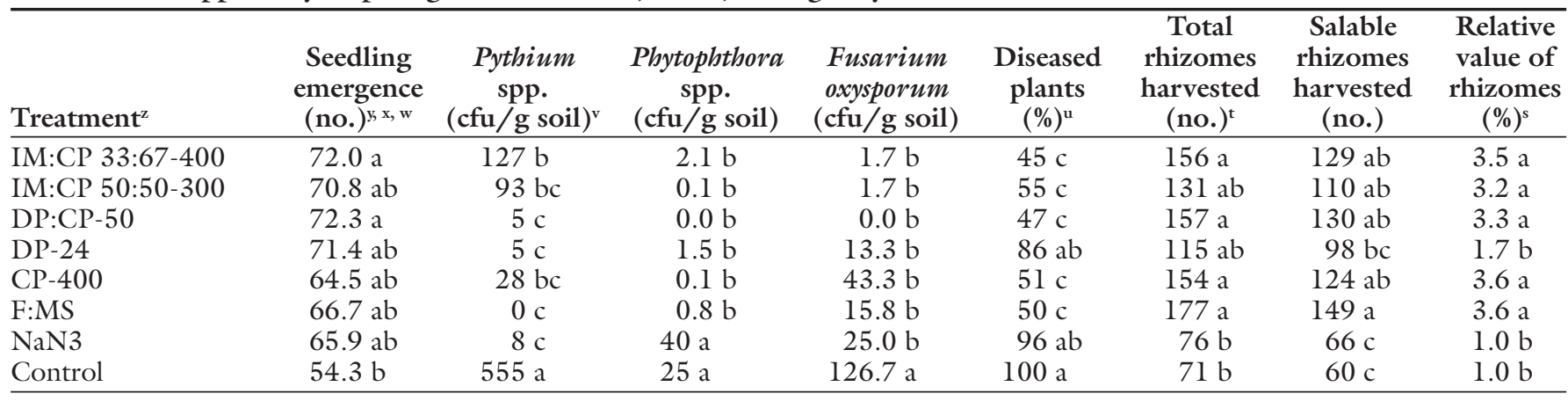

${ }^{2}$ Treatments included IM:CP 33:67-400 = iodomethane + chloropicrin (33:67) at $400 \mathrm{lb} / \mathrm{acre} ; \mathrm{IM}: \mathrm{CP} 50: 50-300=$ iodomethane + chloropicrin $(50: 50)$ at 300 lb/acre; DP $\mathrm{CP}-50=1,3$-dichloropropene + chloropicrin $(6 \mathrm{l}: 33)$ at $50 \mathrm{gal} / \mathrm{acre} ; \mathrm{DP}-24=1,3$-dichloropropene at $24 \mathrm{gal} / \mathrm{acre} ; \mathrm{CP}-400=\mathrm{chloropicrin}$ at $400 \mathrm{lb} / \mathrm{acre} ; \mathrm{F}: \mathrm{MS}=\mathrm{furfural}$ at $480 \mathrm{lb} /$ acre + metham sodium at $210 \mathrm{lb} /$ acre $\left(1.0 \mathrm{lb} /\right.$ acre $\left.=1.1209 \mathrm{~kg} \cdot \mathrm{ha}^{-1} ; \mathrm{l} \mathrm{gal} / \mathrm{acre}=9.3540 \mathrm{~L} \cdot \mathrm{ha} \mathrm{a}^{-1}\right)$.

y eedling emergence counts were made on the center $1 \mathrm{~m}(3.3 \mathrm{ft})$ of the bed in the center six seed lines on 13 Aug. 2002.

${ }^{\mathrm{x}}$ Means not followed by the same letter are significantly different according to Fisher's protected least significant difference test $(P \leq 0.05)$.

wThe emergence of the calla seedlings was significantly greater in the 1 -inch $(25 \mathrm{~mm})$ water treatment $(70.9$ seedlings $)$ compared to the 2 -inch $(51 \mathrm{~mm})$ water treatment (63.6 seedlings).

v $1 \mathrm{cfu} / \mathrm{g}=28.3495 \mathrm{cfu} / \mathrm{oz}$

"Disease counts were made in the center $2 \mathrm{~m}$ (6.6 ft) of each bed on 17 July 2003. The amount of disease was greater in the 2 -inch treatment (70.0\%) compared to the 1 -inch treatment $(62.9 \%)$

tHarvest data collected from the center $2 \mathrm{~m}$ of each bed on 20 Oct. 2003.

${ }^{\text {s}}$ Rhizome value is being expressed relative to the untreated control. Comparisons between trials are not valid.

treatments had better weed control, disease control, plant growth, and yield compared to the water-only treatment in the 2002 trial. The exception is the mortality of the buried mallow seed, where no treatment was different (at $P=$ 0.05 ) from the control (Table 1 ). There was no significant difference among all chemical treatments in controlling the emerging weeds, seedling emergence, and controlling populations of F. oxysporum (Tables 1-2). The DP, F:MS, and $\mathrm{NaN}_{3}$ treatments did not control the buried nutsedge as well as the other chemical treatments. Disease incidence, as indicated by chlorotic and necrotic plants, was greater in the DP and $\mathrm{NaN}_{3}$ treatments compared to the other chemical treatments (Table 2).
The dollar value of the harvested crop was determined based on salability and size. However, prices are proprietary information belonging to the grower, so the value of each treatment is divided by the value of the untreated control so that the relative value of the untreated control is $l$ and the relative value of the other treatments are a multiple of the control. Because of this and other factors, the relative values from the two trials cannot be compared to each other. The crop value from the DP, $\mathrm{NaN}_{3}$, and control treatments are significantly less compared to the rest of the treatments, which are between 3.2-3.6 times the value of the untreated control (Table 2).

There was no detectable popula- tion of Phytophthora spp. in the soil samples from the trial planted in 2003. The data indicate there were no significant differences between any of the chemical treatments and the untreated control for nutsedge control, seedling emergence, or populations of $F$. oxysporum (Table 3). For the rest of the measured parameters, all the chemical treatments performed better than the untreated control (Table 3 ). The three treatments containing the greatest concentrations of $\mathrm{CP}$ produced the highest relative value and were greater than the DP:CP-20 treatments with respect to salable rhizomes and their dollar value (Table 3 ).

These studies show that preplant soil treatments with formulations con- 
Table 3. Counts of volunteer calla lily, nutsedge, emergence of planted calla lily, pathogen populations, disease incidence, and yield data after treatments with various chemicals applied by drip irrigation in Watsonville, Calif., during May 2003.

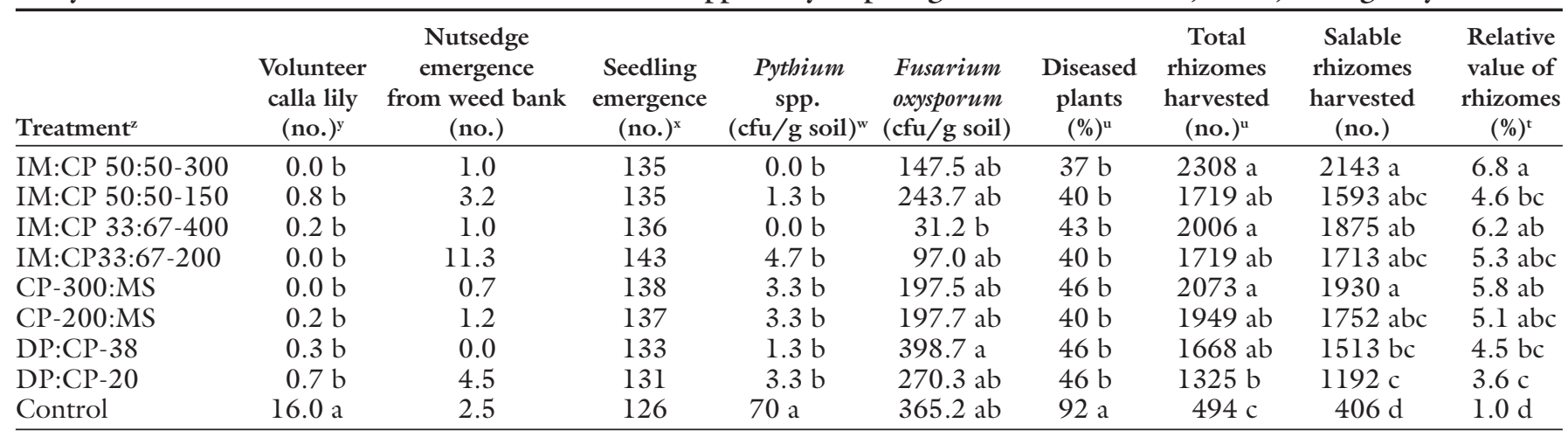

${ }^{2}$ Treatments included IM:CP 33:67-200 = iodomethane + chloropicrin (33:67) at 200 lb/acre; IM:CP 33:67-400 = iodomethane + chloropicrin (33:67) at 400 lb/acre; IM: CP 50:50-150 = iodomethane + chloropicrin (50:50) at $150 \mathrm{lb} / \mathrm{acre}$; IM:CP 50:50-300 = iodomethane + chloropicrin $(50: 50)$ at $300 \mathrm{lb} / \mathrm{acre} ; \mathrm{DP}: \mathrm{CP}-20=1,3-\mathrm{dichloro}-$ propene + chloropicrin (61:33) at 20 gal/acre; DP:CP-38 = 1,3-dichloropropene + chloropicrin (61:33) at 38 gal/acre; CP200:MS = chloropicrin at 200 lb/acre, followed a week later by metham sodium at $75 \mathrm{gal} / \mathrm{acre} ; \mathrm{CP} 300: \mathrm{MS}=$ chloropicrin at $300 \mathrm{lb} / \mathrm{acre}$, followed a week later by metham sodium at $75 \mathrm{gal} / \mathrm{acre}$; and an untreated control $\left(1.0 \mathrm{lb} / \mathrm{acre}=1.1209 \mathrm{~kg} \cdot \mathrm{ha}^{-1} ; \mathrm{l} \mathrm{gal} / \mathrm{acre}=9.3540 \mathrm{~L} \cdot \mathrm{ha}^{-1}\right)$.

'Means not followed by the same letter are significantly different according to Fisher's protected least significant difference test $(P \leq 0.05)$.

${ }^{x}$ Emergence counts were made on the center $1 \mathrm{~m}(3.3 \mathrm{ft})$ of each bed in all 12 seed rows, on 4 Sept. 2003.

"l $\mathrm{cfu} / \mathrm{g}=28.3495 \mathrm{cfu} / \mathrm{oz}$.

Disease counts were made in the center $1 \mathrm{~m}$ of each bed on 13 July 2004.

"Harvest data collected from each entire plot on 15 Dec. 2004.

'Rhizome value is being expressed relative to the untreated control. Comparisons between trials are not valid.

taining CP performed well. Disease was the limiting factor in these studies and $\mathrm{CP}$ is known to control soilborne pathogens (Wilhelm and Storkan, 1990; Wilhelm et al., 1961, 1974). If weeds are a more serious limitation, higher rates of a companion chemical such as IM, DP, or MS will be needed (Haar et al., 2003).

The data show that a successful crop of calla lily rhizomes can be produced using combinations of alternative chemicals applied through drip irrigation systems. Presently, only CP, DP: $\mathrm{CP}$ and metham sodium or potassium are registered for use on ornamental crops, and only the DP:CP-20 rate is registered for calla lily; the DP:CP-38 rate is the maximum rate registered for strawberry (Fragaria xananassa) and is commonly used by strawberry growers in the same counties where calla lily is grown. Registration of the IM:CP formulations will improve the options of calla lily growers to manage disease and weeds in their crops.

\section{Literature cited}

Ajwa, H.A. and T. Trout. 2004. Drip application of alternative fumigants to methyl bromide for strawberry production. HortScience 39:1707-1715.

Ajwa, H.A., T. Trout, J. Mueller, S. Wilhelm, S.D. Nelson, R. Soppe, and D. Shatley. 2002. Application of alternative fumigants through drip irrigation systems. Phytopathology 92:1349-1355.
Dreistadt, S.H. 2001. Integrated pest management for floriculture and nurseries. Publ. 3402, Univ. of California, Oakland.

Fennimore, S.A., M.J. Haar, and H.A. Ajwa. 2003. Weed control in strawberry provided by shank- and drip-applied methyl bromide alternative fumigants. HortScience 38:55-61.

Gerik, J.S. 2005a. Drip applied soil fumigation for freesia production. HortTechnology 15:820-824.

Gerik, J.S. 2005b. Evaluation of soil fumigants applied by drip irrigation for liatris production. Plant Dis. 89:883-887.

Gilreath, J.P., J.W. Noling, and B.M. Santos. 2004a. Methyl bromide alternatives for bell pepper (Capsicum annuum) and cucumber (Cucumis satious) rotations. Crop Protection 23:347-351.

Gilreath, J.P., B.M. Santos, J.D. Busacca, J.E. Eger Jr., J.M. Mirusso, and P.R. Gilreath. 2006. Validating broadcast application of Telone C- 35 complemented with chloropicrin and herbicides in commercial tomato farms. Crop Protection 25:79-82.

Gilreath, J.P., B.M. Santos, P.R. Gilreath, J.P. Jones, and J.W. Noling. 2004b. Efficacy of 1,3-dichloropropene plus chloropicrin application methods in combination with pebulate and napropamide in tomato. Crop Protection 23:1187-1191.

Guo, M., S. Yates, R., S.K. Papiernik, and W. Zheng. 2005. Incompatibility of metham sodium with halogenated fumigants. Pest Mgt. Sci. 61:467-476.

Haar, M.J., S.A. Fennimore, H.A. Ajwa, and C.Q. Winterbottom. 2003. Chloropicrin effect on weed seed viability. Crop Protection 22:109-115.

Jeffers, S.N. and S.B. Martin. 1986. Comparison of two media selective for Phytophthora and Pythium species. Plant Dis. 70:1038-1043.
Kabir, Z., S.A. Fennimore, J.M. Duniway, H.A. Ajwa, B.B. Westerdahl, R.E. Goodhue, F.N. Martin, G.T. Browne, C.Q. Winterbottom, and M.J. Haar. 2005. Alternatives to methyl bromide for strawberry runner plant production. HortScience 40:1709-1715.

Komada, H. 1975. Development of a selective medium for quantitative isolation of Fusarium oxysporum from natural soil. Rev. Plant Protection Res. 8:114-125.

Kuehny, J.S. 2000. Calla history and culture. HortTechnology 10:267-274.

Martin, F.N. 1992. The genus Pythium, p. 39-49. In: L.L. Singleton, J.D. Mihail, and C.M. Rush (eds.). Methods for research on soil borne phytopathogenic fungi. Amer. Phytopathol.Soc., St. Paul, Minn.

U.S. Environmental Protection Agency. 1993; Protection of stratospheric ozone. Federal Register 58:15014-15049.

Watson, R.T., D.L. Albritton, S.O. Anderson, and S.E. Bapty. 1992. Methyl bromide: Its atmospheric science, technology, and economics. Montreal Protocol Assessment Summary. United Nations Environ. Programme, Nairobi, Kenya.

Wilhelm, S. and R.C. Storkan. 1990. Large scale soil fumigation growth response. Phytopathology 49:530-531.

Wilhelm, S., R.C. Storkan, and J.E. Sagen. 1961. Verticillium wilt of strawberry controlled by fumigation of soil with chloropicrin and chloropicrin-methyl bromide mixtures. Phytopathology 51:744-748.

Wilhelm, S., R.C. Storkan, and J.M. Wilhelm. 1974. Preplant soil fumigation with methyl bromide-chloropicrin mixtures for control of soil-borne diseases of strawberries-A summary of fifteen years of development. Agr. Ecosystem Eviron. 1:227-236. 